$$
\text { COAF-83/217--3 }
$$

UCRL-OOOAS

DEDA 005134

\title{
Performance Testing of Waste Forms \\ in a Tuff Environment
}

\author{
Virginia M. Oversby
}

\section{Civilian Radioactive Waste Management \\ Information Meeting \\ Washington, D. C. \\ December 12-15, 1983}

November 1983

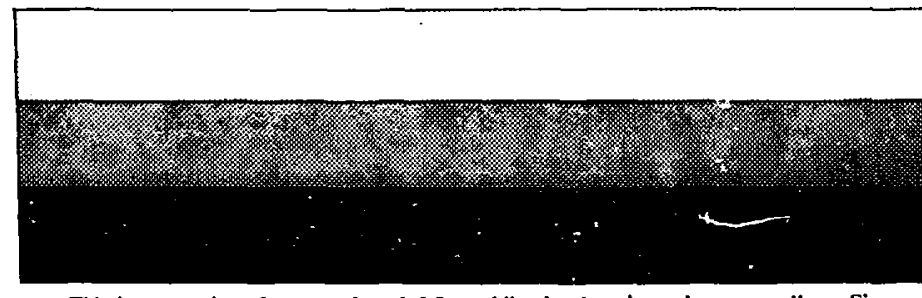

This is a preprint of a paper intended for publication in a journal or proceedings. Since changes may be made before publication. this preprint is made avilable with the understanding that it will not be cited or reproduced without the permission of the author.

\section{DISCLAIMER}

This report was prepared as an account of work sponsored by an agency of the United States Government. Neither the United States Government nor any agency thereof, nor any of their employees, makes any warranty, express or implied, or assumes any legal liability or responsibility for the accuracy, completeness, or usefulness of any information, apparatus, produch, or process disclosed, or represents that its use weuld not infringe privately owned rights. Reference herein to any specific commercial produch, process, or service by trade name, trademark. manufacturer, or otherwise does not necessarily constitute or imply its endorsement, recommendation, or favoring by the United States Government or any agency thereof. The views and opinions of authors expressed berein do not necessarily state or reflect those of the United States Government or any agency thereof. 


\author{
Virginia M. Oversdy \\ Lawrence Livermore National Laboratory \\ Livermore, CA 94550
}

\begin{abstract}
INTRODUCTION
The Nevada Nuclear Waste Storage Investigations Project (NNWSI) is studying the tuffaceous rock units located at Yucca Mountain on the western boundary of the Nevada Test Site. The objective of these studies is to allow an evaluation to be made of the suitabilicy of the Yucca Mountain tuff units as a potential location for a high ievel radioactive waste repository. As part of the NNSWI Project, Lawrence Livermore Nationa? Laboratory is responsible for the design of the waste package and for determining the expected performance of the waste package in the repository environment.
\end{abstract}

The reference horizon for a potential repository at Yucca Mountain is the densely welded, devitrified portion of the Topopah Spring Member of the Paintbrush Tuff (Vieth 1982; Dudley and Erdal 1982). The water table at Yucca Mountain is more than $500 \mathrm{~m}$ deep beneath the central portion of the mountain; as a result, t. Topopan Spring Member lies entirely with in the unsaturated zone (Dudley and Erdal 1982). The mineralogy of the reference horizon is an assemblage of very fine grained alkali feldspar, quartz and cristobalite, with minor amounts of smectite clay. Glass and zeolites are generally absent within the densely welded, devitrified portion of the Topopan Spring (Bish et al. 1981; Caporuscio et al. 1982). The matrix porosity of tne welded tuff is approximately 13 percent, and the rock has a fracture density of 0.8 to 3.9 fractures per meter (Dudley and Erdal 1982).

In order to determine the expected performance of waste package components in the post emplacement repository enyironment we must first develop an

*Work performed under the auspices of the U.S. Department of Energy by the Lawrence Livermore National Laboratory under contract number W-7405-ENG-48. 
understanding of what that environment will be. Geologic, hydrologic and geochemical investigations under way at Yucca Mountain will provide the baseline information for determining the present conditions at the repository norizon. Construction of a repository and emplacement of waste packages would change those conditions.

The major changes which will affect waste form performance in the repository are caused by the thermal and radiation fields resulting from the waste form itself. The thermal output from the waste form will heat the repository rock and vadose water. The water will equilibrate with the rock at temperatures nigher than the present ambient temperature and will change in chemical composition. During the initial heating phase, the repository rock will dry out when the rock temperature exceeds the boiling point of water. Because tne Topopah Spring Member is in the unsaturated zone and is a rather porous, fractured rock, pressures of water which are greater than local atmospheric pressure should not come in contact with the waste packages. Thus, liquid water is not expected to be able to contact the waste packages when temperatures are above $95^{\circ} \mathrm{C}$, the boiling point of water at the repository norizon.

As the thermal power of the waste form decays, the repository rock will cool and eventually the rock will re-establish a partially saturated condition. When the temperature falls below $95^{\circ} \mathrm{C}$, water will be able to exist in the liquid state in the vicinity of the waste packages. That water will have traveled through rock which is at temperatures of up to $95^{\circ} \mathrm{C}$ and will have altered in chemical composition as a result.

This paper will describe experimental work conducted to establish the chemical composition of water which will have reacted with Topopan Spring Member tuff prior to contact with waste packages. The experimental program to determine the behavior of spent fuel and borosilicate glass in the presence of this water will then be described. Preliminary results of experiments using spent fuel segments with defects in the Zircaloy cladding will be presented. Some results from parametric testing of a borosilicate glass with tuff and $304 \mathrm{~L}$ stainless steel will also be discussed. 
There are presentiy no samples of water available from the unsaturated Topopah Spring Member horizon. To obtain water samples which are as close as possible to what we expect to be present at the repository level we have chosen to use the well J-13 water. This well is located suveral miles to the southeast of Yucca Mountain. At this location the Topopah Spring Member is at a lower elevation and lies in the saturated zone. The main producing horizon for $\mathrm{J}-13$ water is tne Topopah Spring Member; therefore, J-13 water should represent the ambient temperature water chemistry for water equilibrated with the Topopan spring Member tuff.

The rock samples which we have used in most of our experiments were collected from an outcrop of Topopah Spring Member on the southern part of Fran Ridge, a ridge which lies between Yucca Mountain and $3-13$ well. These samples contain some very soluble salt deposits in their pores. This soluble material is present due to the arid surface conditions and is removed before hydrotnermal testing (Knauss et al. 1983). Some experiments have also used drill core samples of Topopan Spring Member tuff to evaluate lateral variations in chemistry which might occur. A description of the experimental procedures is given by Oversby and Knauss (1983) and Knauss et at. (1983).

Rates of equilibration between silicate minerals and waters of near neutral pH are very slow at low temperatures. In order to obtain kinetic data for geochemicat modeling we have conducted experiments at $90^{\circ} \mathrm{C}$, which is close to the maximum liquid water temperature expected in the repository horizon, and at $150^{\circ} \mathrm{C}$, whicn far exceeds the temperature at which liquid water should be present. Data will te presented below for both temperatures; however, it should be remembered that the $90^{\circ} \mathrm{C}$ data is the more representative of expected conditions.

Tnree types of hydrothermal experiments were done using Topopah Spring tuff: (1) crushed tuff reacted with J-13 water in teflon reaction vessels, (2) tuff core wafers reacted with $\mathrm{J}-13$ water in teflon reaction vessels, and (3) crushed tuff reacted with $\mathrm{J}-13$ water in Dickson-type gold cell rocking 
autoclaves. We have found that all three types of experiments were necessary to gain a full understanding of the rock-water system. The discussion which follows will highlight some of the principle findings from the experiments and show how the experiments contribute to developing an understanding of the post emplacement environment of the repository.

Experiments using crushed Topopah Spring tuff and J-13 water are conducted using a test matrix which varies reaction time and rock to water ratio at each temperature. Details of the test matrix are given in knauss et al. (1983). All samples were pretreated to remove the readily soluble salt material. Reaction of the pretreated crushed tuff with $\mathrm{J}-13$ water at $90^{\circ} \mathrm{C}$ and $150^{\circ} \mathrm{C}$ does not release $\mathrm{F}^{-}, \mathrm{Cl}^{-}, \mathrm{NO}_{3}^{-}$, or $\mathrm{SO}_{4}^{-}$to the solution in amounts larger than a few ppm. The amount of the anion release is independent of temperature and is roughly proportional to rock weight at constant water volume. This suggests the complete solution of a trace soluble component which was not removed during the pretreatment step (Oversby 1984a).

The primary reasons for using crushed tuff in the hydrothermal reactions are to increase the surface area of rock particles and allow more rontact between the rock and water, and to allow experiments to be conducted in small vessels and thus increase the number of experiments which can be run. These experiments will provide information on the reaction path and the kinetics of rock-water reactions.

Figure 1 shows some of the experimental data for $\mathrm{Ca}$ and $\mathrm{Al}$ at $90^{\circ} \mathrm{C}$ and $150^{\circ} \mathrm{C}$. Calcium in solution decreases with reaction time. The decrease is greater at the higher reaction temperature, as would be expected from the retrograde solubility of calcite. The precipitation reaction is slow, especially at $90^{\circ} \mathrm{C}$. Magnesium, which is $1.8 \mathrm{ppm}$ in $\mathrm{J}-13$ water, precipitates faster than $\mathrm{Ca}$, and is enriched in the centers of calcite crystals which are found on the surface of reacted core wafers. Aluminum concentrations at $150^{\circ} \mathrm{C}$ rise on reaction with the tuff and then slowly decrease. This appears to be supersaturation due to colloid formation, followed by slow coagulation. The degree of supersaturation at $90^{\circ} \mathrm{C}$ is much less than at $150^{\circ} \mathrm{C}$, suggesting that the importance of colloids is less at the lower temperature. 


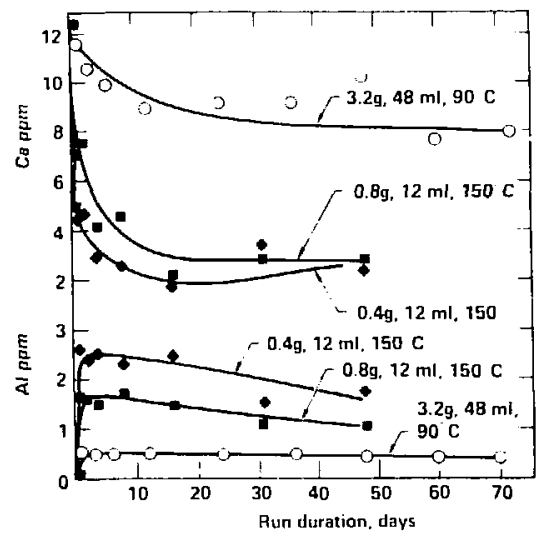

Fig. 1 Calcium and aluminum concentrations versus reaction time for pretreated Topopah Spring tuff with J-13 water. Curves are labeled with rock weight, $\mathrm{J}-13$ volume and reaction temperature.

Silicon in solution increases slowly due to dissolution of quartz and cristobalite. Data are shown in Fig. 2 for a single rock/water ratio vs. reaction time. The solubility of silica is much higher at $150^{\circ} \mathrm{C}$ than at $90^{\circ} \mathrm{C}$, and appears to be controlled by cristobalite rather than quartz. The $\mathrm{pH}$ of the solutions, 8.5 at $90^{\circ} \mathrm{C}$ and 9.0 at $150^{\circ} \mathrm{C}$, is somewhat higher than that predicted based on geochemical modeling calculations for the observed silica levels. This is especially true for samples of J-13 water heated without rock ( $J-13$ blanks) which have only 20 to $25 \mathrm{ppm}$ Si after neating.

The high $\mathrm{pH}$ is attributed to loss of $\mathrm{CO}_{2}$ to the teflon. J-13 carbonate alkalinity is $2.16 \mathrm{meq} / 1$, which corresponds to $132 \mathrm{ppm}$ when calculated as $\mathrm{HCO}_{3}^{-}$. Reaction at $90^{\circ} \mathrm{C}$ reduced alkalinity to approximately $1.8 \mathrm{meq} / 1$ ( $110 \mathrm{ppm})$ and reaction at $150^{\circ} \mathrm{C}$ reduced alkal inity to approximately 1.5 meq/l (92 ppm). Samples of J-13 water heated without rock showed somewhat greater reduction in alkalinity. Most of the reduction in alkalinity can be correlated with the decrease in $\mathrm{Mg}$ and $\mathrm{Ca}$; however, especially in the case of the $\mathrm{J}-13$ blanks, there must also be some loss of $\mathrm{CO}_{2}$ to the teflon. This is confirmed by the results of the gold bag autoclave experiments (discussed below) which give final $\mathrm{pH}$ of approximately 7.0 . 


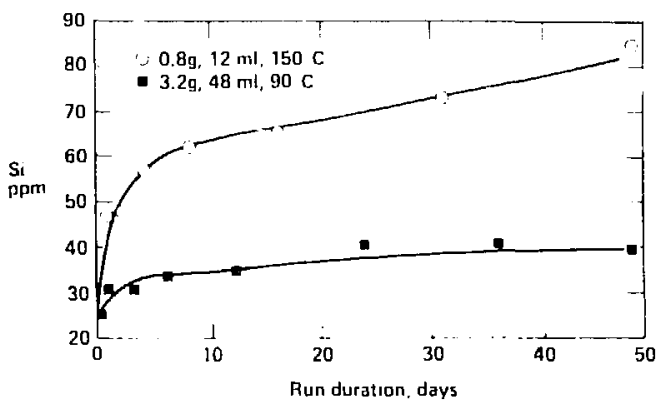

Fig. 2 Silicon concentration in solution for reaction of pretreated Topopah Spring tuff witn .3-13 water.

Sodium concentrations in solution after reaction are essentially the same as the $\mathrm{J}-13$ starting values at botn temperatures. Potassium shows an increase from $b .3 \mathrm{ppin}$ to values between 7 and $10 \mathrm{ppm}$; the values increase as the ratio of rock to water is increased and correlate with the slight increase in anion concentration (Oversby 1984a). This suggests that the $K$ increase is due to the incomplete removal of the original soluble components during pretreatment of the crushed rock.

In order to estimate the degree of variability in water chemistry which might result due to lateral variability in the mineralogy of the repository horizon, we have used Topopan Spring tuff samples selected from the uppropriate depth interval from three vertical drill holes (G1, GU3 and GA) and one norizontal air drilled hole (HI) at Fran Ridge. These samples were subjected to the pretreatment procedures and were found to contain no readily soluble components. This finding is particularly significant in the case of the Fran Ridge samples, since the air drilled hole is close to the surface outcrop from which our other Fran Ridge samples were collected. As a result of this data, we do not expect that we will encounter large amounts of soluble anion material at the repository horizon. Solution concentrations for pratreated samples which were reacted with J-13 water for 64 days at $150^{\circ} \mathrm{C}$ are given in Fig. 3. The sample number gives the distance in feet from the surface at which the sample existed in situ. Solution data for these samples is very similar except for GU3-1072 ft. which shows clear evidence for precipitation 
of a silicate phase ( $\mathrm{Na}$ is also low for this sample) and for two samples which are somewhat low in $\mathrm{Si}$. The main difference between these samples and those discussed previously is in the $K$ concentrations. Other data for shorter reaction times is similar to that for the Fran Ridge outcrop material which indicates that these samples nave precipitated $k$ from solution during the longer reaction time.

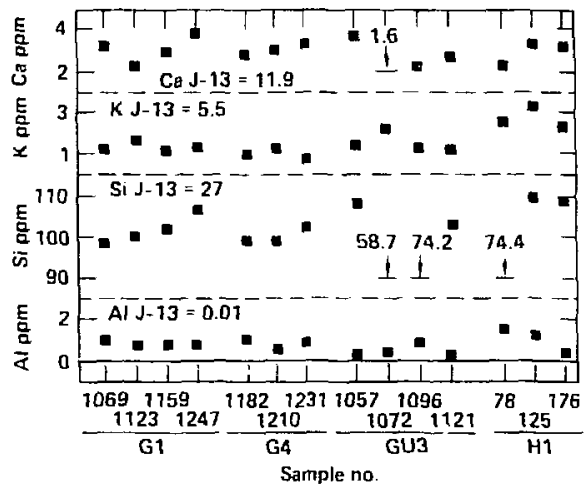

Fig. 3 Solution concentrations for drill core samples of Topopan Spring tuff reacted with $\mathrm{J}-13$ water for 64 days at $150^{\circ} \mathrm{C}$.

Hydrothermal experiments with crushed rock have several limitations. First, it is not possible to study the chemistry of the solid phases after reaction using conventional techniques which require a polished surface for accurate analysis. Second, it is difficult or impossible to identify secondary phases or precipitates formed during the reaction. Third, there is uncertainty whether water in contact with intact rock will show similar reaction kinetics to those determined for crushed rock. This is because of surface alteration introduced during the crushing procedures and because water access to the rock may be slowed due to the lower permeability of the intact rock relative to uncompacted crushed rock.

In order to address these limitations, we have conducted experiments using polished core wafers of Topopah Spring tuff. Details of the experiments are given in Knauss and Beiriger (1984). Two types of experiments were done; first, core wafers were submerged in $\mathrm{J}-13$ water and reacted at $150^{\circ} \mathrm{C}$ in 
teflon containers. Results of these experiments can be directly compared to those using crushed tuff. The second type of experiments subjected core wafers to water saturated iir. The water saturation of the air was obtained by using an amount of $\mathrm{J}-13$ water in the reaction vessel which was sufficient to saturate the air at the reaction temperature plus a 5 light excess to allow refluxing. On cooling of the reacted material, the water was recovered as liquid. Both types of tests were run at $150^{\circ} \mathrm{C}$ for periods of up to 4 months. The core wafer samples were not pretreated to remove soluble material; nowever, large amounts of watn worc used in the preparation of the wafers which effectively removes most of the readily soluble material.

Results of the submerged core wafer tests (Knauss et al. 1983) were in excellent agreement with the data obtained using crusned rock samples for all elements except $\mathrm{Al}$ and $\mathrm{Si}$. Tho crushed samples gave nigher Al concentrations; these samples were rolled during the reaction period and the resulting agitation may have stabilized colloidal material in suspension. The Si concentrations are nigher in the core wafer experiments. This is mainly due to the longer reaction time; there may also be a small amount of "glassy" material formed during the polishing of the core wafers prior to reaction (Oversby and Knauss 1983). Data for samples run in water saturated air showed similar results, but all reaction rates appear to be slower.

Scanning electron microscope and electron microprobe analyses of reacted core wafers showed no changes in the chemistry of major pnenocrysts (plagioclase, sanidine and biotite) or the matrix assemblage due to hydrothermal reaction. However, abundant discrete calcite crystals were formed on all submerged samples. The calcite crystals were found to have Mg enriched cores. The identified precipitated phase and the lack of reaction shown by the primary phases correlate well with the solution cnemistry found after reaction. Essentially all that happens during the hydrothermal reaction period is the precipitation of magnesian calcite and the dissolution of some cristobalite.

The combination of the crushed tuff experiments with the core wafer testing still leaves two issues unresolved. They are: (1) what is the effect of loss of $\mathrm{CO}_{2}$ to the teflon containers?, and (2) is there any change in solution chemistry when the solutions in the teflon capsules are cooled after 
completion of the reaction period? In order to resolve these issues, we have conducted some experiments in Dickson-type gold cell rocking autoclaves. These autoclaves provide a chemically inert and gas tight reaction vesse] which ensures that $\mathrm{CO}_{2}$ will not be lost from the solutions to the reaction vessel. They also allow samples to be taken at the reaction temperature, and thus avoid the potential for solution chemistry changes due to quenching effects. Pretreated crushed Topopah Spring tuff and J-13 water were reacted at $150^{\circ} \mathrm{C}$ in duplizate autoclave experiments for 32 days. The details of the experiments are described by Knauss and Peifer (1984). Agreement between data for $\mathrm{Ca}, \mathrm{S} i$ and $\mathrm{Al}$ for teflon vessel experiments and the gold cell experiments was excellent and indicites that quenching is not a problem in the teflon vessel experiments. The major difference between the two types of experiments was in the $\mathrm{pH}$ of the solutions. The $\mathrm{pH}$ in autoclave runs drops initially to slightly less than 7 and then rises slowly to values which are slightly greater than 7 . The initial drop in pH is due to carbonate precipitation. Alkalinity in the gold cells remains essentially constant during the reaction time, while alkalinity in the teflon containers decreases. This suggests that the difference in $\mathrm{pH}$ is due to loss of $\mathrm{CO}_{2}$ to the teflon containers.

The risults from the three types of rock-water interaction tests can be summarized to show that there will be very little change in water chemistry due to interaction of vadose water with the rock on the path through the repository before contact with the waste packages. We see no significant increase in anion concentration in the water due to interaction with the rock and there is no evidence to suggest that the readily soluble component found on surface outcrop samples will be present at depth. This is an important finding because some anions such as fluoride and chloride can cause or enhance localized corrosion of canister materials. Other anicns might act as complexing agents and enhance the mobility of radicnuclides. The absence of a source of anions is, therefore, of assistance to the performance of the waste packaje. The $\mathrm{pH}$ of the solutions when runs are conducted in vessels that do not consume $\mathrm{CO}_{2}$ remains nearly neutral. This will enhance the durability of borosilicate glass which shows higher dissolution rates at $\mathrm{pH}$ less than $5 \mathrm{or}$ greater than 9 (Plodinec et al. 1982). The increase in silica concentration of the water as a result of reaction with the rock will also assist the durabjlity of borosilicate glass since the dissolution rate of such glasses 
decreases as the silica content of the solution increases (McVay lyB:'). "W. lack of detectable alteration of the primary mineral phases in the rock suggests that the long tarm behavior of the rock snould be similar to the oehavior ooserved in relatively short terin experiments. The only secondary mineral produced in the reactions in significant amounts was $(\mathrm{Ca}, \mathrm{Mg}) \mathrm{CO}_{3}$. Production of this phase should not have any adverse effect on the performance of the waste form or the container. The uniformity of chemical data from reaction of samples of Topopan Spring tuff taken from widely separated localities is encouraging. Thij suggests that the total water cnemistry for the post emplacement condition of the repository should be fairly easy to model using the results of laboratory experiments and geochemical modeling codes.

\section{WASTE FORM STIDDIES}

In urder to ensure containnent of the radioactivity for the first 300 to 100 ) years after disposal of the waste in tne repository, the waste form will be protected by a 304L stainless steel container. Estimates of corrosion rates for $304 \mathrm{~L}$ in the Yucca :Aountain environment give a conservative upper 1 imit of $0.1 \mathrm{~cm}$ per 1000 years for metai loss by uniform corrosion (Mcirignt et al. 1933). Inus, for the first 10,010 years the environinent of the waste form will contain $304 \mathrm{~L}$ stainless steel. The most likely mechanism to cause treach of the container in the tuff environment is some form of stress corrosion (McCright et al. 1983). This assessment, combined with the low uniforin corrosion rate, suggests that the waste form will be neid in the $304 \mathrm{~L}$ rontainer for 10,000 years but the container will eventually develop some cracks which allow water to gain access to the waste form.

Precise determination of the release rate of radionuclides from the container after breach occurs will require the following information:

(1) Amount of water which will contact the container;

(2) How much of that water will gain access to the waste form;

(3) How much waste form material will dissolve in the water which contacts the waste form;

(4) How mucn of the water containing radionuclides will escape from the container. 
This information requires a thorough understanding of the hydrology at the repository and the corrosion behavior of the container in addition to the need for data on the dissolution rate of the waste form in aqueous solutions of the appropriate chemical composition.

It will be many years before we have sufficient data to give a good picture of the actual rate of release of radionuclides from a waste form held in a oreached 304L container. However, we can make some simplifying assumptions which will allow us to determine the upper bound on the rate of release. The first assumption concerns the amount of water whicn is available to contact the waste form. In the unsaturated zone, the rate of flow of water is limited oy the downward infiltration rate of water. Sass and Lachenbruch (198?) estimated that the ayerage infiltration rate is $8 \mathrm{~mm} / \mathrm{yr}$ tnrough the unsaturated zone at NTS. Ising that infiltration rate, we can calculate "ie amount of water which will flow through the repository each year. The result is 8 liters of water per square meter of surface area per year. For a vertical emplacement hole with a $100 \mathrm{~cm}$ diameter the volume of water would be $6.3 \mathrm{l} / \mathrm{yr}$ if only the downward flux is considered and no concentrating mechanism is envaked.

To abtain a reasonable upper bound on the water availability we have calculated the amount of water encountering areas of rock which were disturbed by repository construction. We have then assumed that any water which encounters a disturbed area is evenly distributed among the waste packages. For the purposes of this calculation, we have assumed that $15 \%$ of the total renository area is disturbed and that the parkage density is 120 per acre for DHLW and 23 per acre for CHLW. The results of the calculation give $401 / \mathrm{yr}$ per DHLW package and 208 1/yr per CHL'W package as a reasonable upper limit for water availability. For spent fuel packages the result is approximately 300 l/yr per reference $3.3 \mathrm{~kW}$ package, which corresponds to approximately $250 \mathrm{ml}$ per fuel pin. Waste form testing will be conducted to cover the range of water availability estimates.

The second assumption which can be made concerns how much of the total water which contacts a breached container will also contact the waste form. For most of the period from 1000 to 10,000 years after disposal only a small 
Fraction of the water which contacts a rontainer will actually enter the container through a breach. The majority of the water should encounter intact steel and not contact the waste form. Thus, it will be a conservative upper I imic, if we assume that all water which contacts the waste packages also is aole to interact with the waste form and escape from the container. In urder to include tnis assumption in our testing program, we will include $304 \mathrm{~L}$ stainless steel as a component of the waste form tests but will not allow the steel to significantly impede contact of the water with the waste form.

NNWSI waste form testing for reprocessed waste is conducted using PNL 76-68 borosilirate glass formulation as the reference CHLW form. Three versions of this glass are being used:

(1) Siniulated fission products + uranium;

(2) Simulated fission products + all actinides $+T C$;

(3) "Aged" glass - formulated to represent glass 300 years after disposal. The reference waste form for DHLW is based on the Savannah River Laboratory borosilicate glass using 165 frit. Two versions of this glass are tested:

(1) Simulated fission producis + uraniun;

(2) Fully loaded glass using actual SRP waste.

Detailed descriptions of these waste forms are given by Oversby (1984b).

Three types of testing will be done to determine the behavior of these reprocessed waste forms under expected repository conditions. First, parametric testing will be used to determine release rate from the waste form as a function of system components and variables. The parameters which will be investigated include waste form composition, waste form surface area to water volume ratio (SA/V), temperature, presence and nature if corrosion products, water chemistry, and radiation. To date, the effects of $S A / V$, temperature and metal components have been investigated using U-doped simulated 76-68 glass (McVay and Robinson 1983).

Figure 4 shows results for boron release from PNL 76-68 glass at $90^{\circ} \mathrm{C}$ with a glass surface area to solution volume ratio of $0.1 \mathrm{~cm}^{-1}$. This SA/V is far lower than that expected for repository conditions; it was chosen to allow comparison of the parametric results to existing MCC-l distilled water leaching data for $76-68 \mathrm{glass}$. Boron represents 2.7 percent of the glass, and 
since it has a high solubility in aqueous solutions, should be a good measure of glass matrix dissolution rate. The largest release of boron occurs for glass reacted with J-13 water without rock present. When a rock "monolith" (Tpt M) is added to the system, release of boron is less. This is because tne rock now contributes $5 i$ to the solutions which reduces the dissolution rate of the glass. Addition of $304 \mathrm{~L}$ stainless steel to the system lowers the release rate of boron even further. This is in contrast to the behavior of glass in the presence of carbon steel where leaching of glass is increased due to metal corrosion products reacting with $5 i$ and lowering solution $5 i$ concentrations (McVay 1982).

The curve labeled 76-68 + J-13 + Tpt $P$ represents data for the glass in the presence of crushed tuff. The crushed tuff increased solution $5 i$ more rapidly than the tuff monolith, and consequently less glass was able to dissolve.

Since water which contacts the waste form in the repository environment will have Si concentrations which were increased due to passage through heated rock, this curve is probably more representative of the release rate of boron

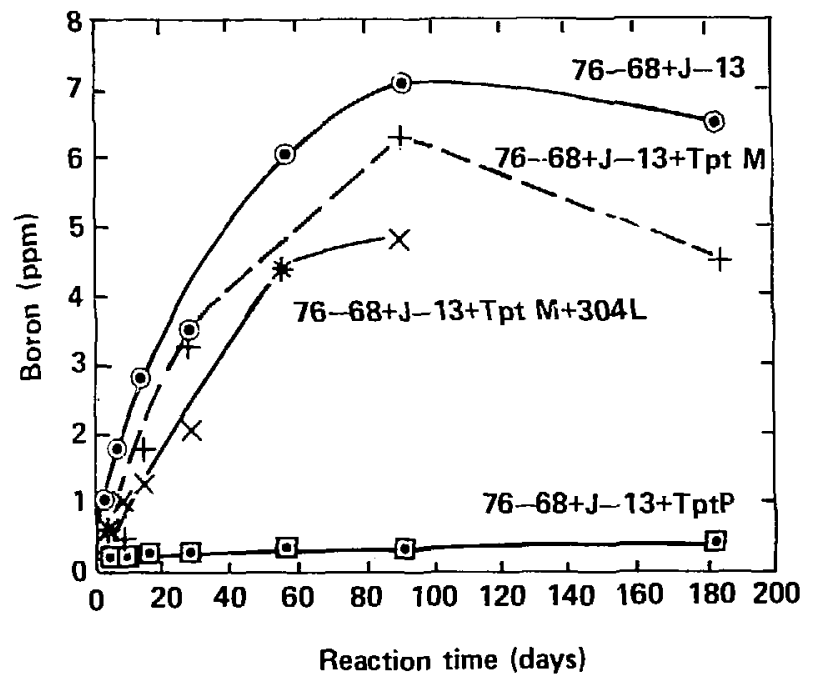

$\tilde{r}$ ig. 4 Boron concentrations as a function of reaction time for parametric testing of PNL 76-68 glass in J-13 water. Curve 1 abeled + Tpt $M$ is data for glass + J-13 + tuff monolith; + Tpt M + 304L is data for glass + J-13 + tuff monolith $+304 L$ stainless steel $;+$ Tpt $F$ is data for glass + J-13 + crushed tuff. Reaction temperature $=90^{\circ} \mathrm{C}$. Glass $S A$ / solution $v=0.1 \mathrm{~cm}^{-1}$. 
(and glass dissolution rate) to be expected in the repository environment than the Tpt M curve.

Figure 5 shows data for boron release from 76-68 glass reacted with $\mathrm{J}-13$ water at $90^{\circ} \mathrm{C}$ in the presence of crushed tuff, and in one case with crushed tuff + $304 \mathrm{~L}$ stainless steel. The surface area of the glass was increased by crushing the glass to produce $(S A / V)=1 \mathrm{~cm}^{-1}$. Boron concentrations in solution are similar to those in Fig. 4 for glass + crushed tuff, indicating that no further dissolution of glass occurred at the higher SAN. Also, crusning of the glass does not appear to increase the dissolution rate. If the dissolution rate inferred from this data and the Tpt $P$ curve in Fig. 4 is adjusted for $B$ contributed by $\mathrm{J}-13$ and then scaled to a full size waste package by allowing for the differences in glass surface to glass volume ratio, the calculated annual release rate from the full size waste form is less than 1 part in 100,000 per yea". Increasing the amount of rock present in the svistem from $0.1 \mathrm{~g}$ to $1 \mathrm{~g}$ produced only a small change in dissolution rate of the glass. The presence of $304 \mathrm{~L}$ stainless steel in the system did not increase the dissolution rate of the glass, and may actually have caused a slight decrease in the glass dissolution rate.

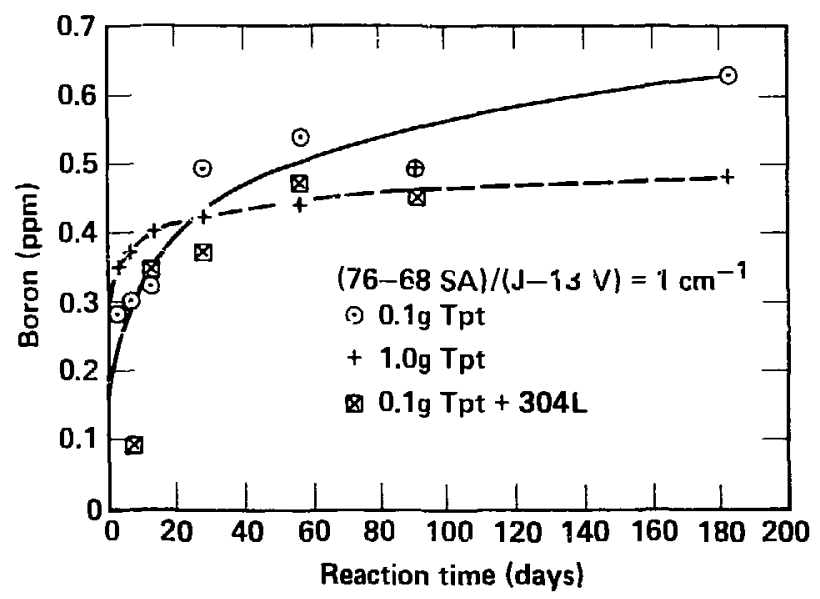

Fig 5. Boron concentration in solution for the reaction of PNL 76-68 glass with $\mathrm{J}-13$ water + components 1 isted by data symbols at $90^{\circ} \mathrm{C}$ as a function of reaction time. Tpt is crushed Topopah Spring Member tuff; $304 \mathrm{~L}$ is $304 \mathrm{~L}$ stainless steel. 
The second type of reprocessed waste form testing will address the events and processes which are anticipated to occur in the repository horizon. The transport of water in the unsaturated Topopan Spring Member tuff will involve a combination of porous media and fracture flow. In either case, the likely mechanism for delivery of liquid water to the waste form surface will be by dripping from the borehole surface. Some water may aiso condense onto the waste form from the vapor phase. To aid in gaining an understanding of the release rates and mechanisms under unsaturated flow conditions, we have developed a test method to simulate the expected conditions.

The unsaturated test method will use a reaction vessel rabricated from 304L stainless steel. The waste form will be cylindrical with perforated end caps of stainless steel to simulate a corroded canister. The waste form will be suspended over a tuff cup which will collect iny fluid which drips off the waste form. Water whicn has been preconditioned by reaction with tuff will be dripped onto the top of the waste form assembly. For DHLW samples with a surface area of $15 \mathrm{~cm}^{2}$, the drip rate appropriate to 401 per DWPF canister per year is approximately one drop $(0.1 \mathrm{ml})$ per 3 days. The test will be run at $90^{\circ} i$ for periods of time up to 1 year.

The mechanisms of waste form alteration under the conditions of the unsaturated test include dissolution of glass in liquid water as well as alteration of the glass by vapor and liquid films on the glass surface. To monitor the extent of reaction of the glass several types of post-test measurements will be done. These measurements will include solution analyses of any liquids present, rinsing of the tuff to collect any readily soluble material adhering to the rock surface, rinsing of the steel container, analysis of surface alteration products on the waste form, and depth profiling through the tuff cup to determine the extent of penetration of radionuclides.

The unsaturated test method will be refined after preliminary trials now in prumess are completed. The test will then be employed using samples of uranium doped simulated DHLW glass and CHLW glass. The results of these tests should provide a reliable estimate for radionuclide release from the waste form under anticipated repository conditions. 
The third type of reprocessed waste form testing involves tests under canditions where the glass is submerged in water. This type of testing is appropriate to conditions of full saturation such as exist below the water table. In the unsaturated zone standing water majy accumulate if pores and fissures become plugged and allow water to accumulate. Evidence collected to date suggests that development of perched water in the Topopah Spring Member is unlikely (Morrow et al. 1983). Thus, saturated testing of waste forms provides data on release rates under conditions of unanticipated processes and events. These tests should also provide an upper limit on release rates of radionuclides from the glass under all reasonably possible conditions.

Saturated testing will use the estimates of maximum water availability given above scaled to the specimen size used in the tests. Scaling will presume that both the test specimens and the full size waste forms are uncracked monoliths. (This is true for the test specimens; the full size canisters will have additional surface area due to cracking. The effect of this additional surface area will be assessed using tha results of the parametric tests described above.) For testing purposes we will assume that the full annual allowance of water is in contact with the waste form for a full year. Since supersaturation effects are not expecied to occur for matrix elements of the glass, this assumption will provide an upper limit to the waste form dissolution rate. The issue of whether supersaturation can occur will be addressed as fa:t of the parametric testing program.

Saturated tests will be conducted in tuff reaction vessels. The tuff will be pre-saturated with J-13 water, placed in an inert container, and J-13 water will be added to both the outer container and inside the tuff vessel. Giass samples, or glass + 3J4L stainless steel, will be suspended in the liquid pnase. The tuff vessel will be covered with a loose fitting lid of tuff and the outer inert container will be closed. Testing will be conducted at $90^{\circ} \mathrm{C}$ for periods of time up to one year.

Testing of $\mathrm{DHLW}$ forms under saturated conditions is currently in progress using both simulated and fully active waste forms. Testing of actinide doped PNL 76-68 glass will begin in the near future. Post-test analyses will include samples of solutions taken from inside and outside the saturated tuff 
vessel. This will allow an assessment of the extent of migration of radionuclides through the tuff. The waste form will be examined for surface alteration and development of chemical composition gradients. The effects of canister corrosion products will be assessed by running tests both with and without canister materials. Radiolysis effects will be estimated through comparison of results from simulated and fulty active glasses. Radionuclide migration will be estimated by examination of tuff reaction vessels after completion of the tests.

The NNWSI testing program for spent fuel has been designed to evaluate the performance of Zircaloy $\mathrm{Clad} \mathrm{UO}_{2}$ in the Topopan Spring tuff environment. The Zircaloy cladding on spent fuel provides a containment barrier against release of radionuclides for as long as the cladding remains intact. The population of fuel which will be delivered to the repository should contain less than $0.1 \%$ of fuel pins which have breached cladding (Woodley 1983). Breach typically occurs as a pin-hole defect or a stress corrosion crack. Our spent fuel testing prugram will evaluate the release rate of radionuclides from fuel pins which contain defects in the Zircaloy cladding relative to the release rate from bare $U_{2}{ }_{2}$ fuel pellets. The experimental work is being conducted by the Westinghouse Hanford Company.

Initial testing of spent fuel is being conducted in deionized water at ambient not cell temperatures (approximately $25^{\circ} \mathrm{C}$ ). Test specimens are 5 inch long segments of PWR fuel with burnup of approximately 26,000 MWD/MTHM. The specimens are fitted with water tight end caps. The test matrix includes three control specimens of undefected fuel plus cladding, one control specimen consistiny of the fuel removed from the cladding, a pin segment into which a 200 micron diameter iole was burned witn a laser, a pin segment containing two laser punctures, dird a pin segment into which a s7it 150 microns wide by 2.5 cin long was machined.

Pin segments fitted with end caps are placed in a vertical orientation in a fused quartz reaction vessel. The upper end cap is vented to allow easier access of water through defects in the cladding. Fused quartz rods are placed in the container; they are used to monitor plate-out of radionuclides during the test. Water is added to the quartz vessel up to the level of the top end 
cap. The solution volume is approximately $200 \mathrm{ml}$. A loose fitting quartz lid is placed over the quartz vessel. The bare fuel control sample uses the fuel placed on the bottom of the quurtz vesse? with an amount of water equal to that used in the other tests. The cladding material from which the fuel was removed is placed in the quartz vessel with the bare fuel.

Solution samples are removed for radiochemical analysis after 1, 5, 15, and 30 days and every 30 days thereafter until termination of the test. After sampling, deionized water is added to replace the volume of solution removed. Fused quartz rods are pulled periodically and any plated out material stripped from them using acid. Upon completion of the tests the quartz vessel will be analysed for plated out radioactivity.

Figure 6 shows data for uranium in solution as a function of reaction time. Tne line labeled "hole" is for the two puncture specimen. For reference, the solution concentration equivalent to one part in $10^{5}$ of the fuel inside the pin segment is shown. Solution concentrations appear to have reached stead; state in all cases, with the laser puncture specimen showing concentrations which are only slightly higher than the intact control specimen.

Data for uranium plated out onto quartz rods is given in Figure 7 . After 30 days the quantity of uranium on a single rod has essentially stabilized at 60 to $80 \mu \mathrm{g}$ for the bare fuel, $0.5 \mu \mathrm{g}$ for the slit defect, and less than 0.1 ug for both the hole defect and the control specimen. This corresponds in the case of bare fuel to an amount of $U$ equivalent to or greater than that in solution being plated out onto each rod. Clearly the solution became supersatured early in the iest. (Fig. 6) and then precipitated $U$ to reach solution concentrations controlled by solubility. The amount of plate-out in the case of the slit defect is approximately $1 / 10$ of the solution total $U$ per rod. For the hole defect, the plate-out is also about $1 / 10$ of the solution total $U$ but is an order of magnitude lower in absolute abundance than the slit defect case. Data for other radionuclides are available and will be presented in a more detailed technical publication. 


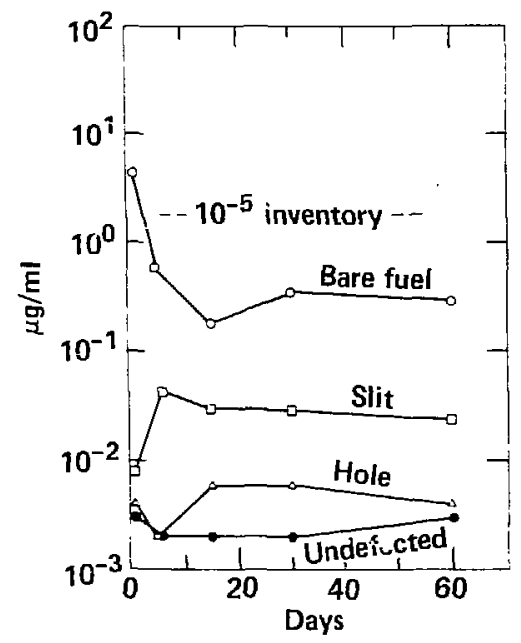

Fig. 6 Uraniuni concericration in solution for spent fuel segments submerged in $200 \mathrm{ml}$ of deionized water. The undefected sample is a control specimen of Zircaloy clad fuel. The hole sample contains two laser puncture defects.

The deionized water experiment witl be continued for long enough to confirm that steady state conditions have been achieved. At the conclusion of the test tne specimens will be examined to determine the extent of alteration of the induced defects in the $\mathrm{cladding}$ and the fuel inside the defected cladding.

A new series of cladding defect tests will be conducted this year using J-13 well water. A parallel series of tests will analyse the effect of adding Topopah Spring tuff to the system. Testing at elevated temperatures will also be done.

In order to show that cladding will provide a barrier to radionuclide release from spent fuel it is also necessary to investigate the corrosion rates and mechanisms of Zircaloy in the repository environment. An experinental program will begin this year to investigate the following topics: (1) what is the rate of production of defects in cladding during the containment period; (2) what alteration occurs to existing and newly produced defects during the containment period; (3) what is the production rate of defects after water gains access to the cladding; (4) what is the alteration which occurs to defects in an aqueous corrosion enviranment? 


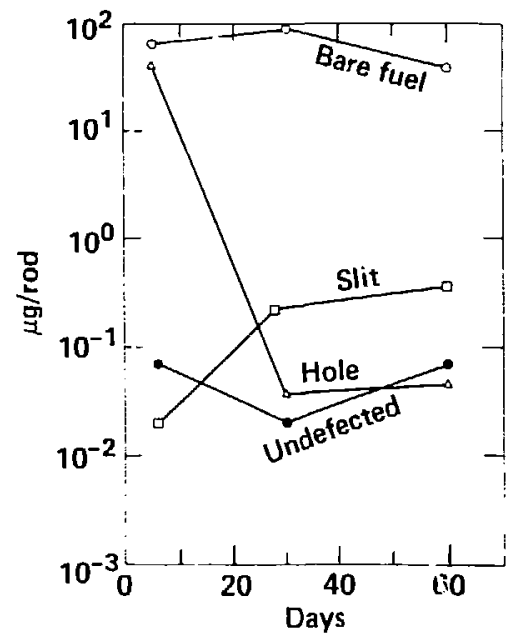

Fig. 7 Total uranium deposited on une quartz rod which had remained in the test solutions ior the total time shown on the horizontal axis. See Fig. 6 for solution concentrations.

The data obtained from the corrosion experiments will be combined with tnat from the relative release rate cesting to determine the time dependent release rate of radionuclides from the spent fuel population. This will be accomp? ished by:

(1) Estimation of the population of fulel pins which will be delivered to the repository with defects in ine cladding;

(2) Estimation of how many new defects will be formed during repository handling operations and by Zircaloy failure during the containment period;

(3) Determination of the expected change in defect character during the containment period;

(4) Calcuiation of release rate by assuming that rods with no defects produce no release and using the experimental results to provide release rates for other cases;

(5) Adjust the defect population as a function of time to allow for production of new defects and enlargement of existing defeits;

(6) Recalculate release rate for new conditions. 
Preliminary results indicate that release rates calculated on this basis will be lower than 1 part in $10^{5}$ per year of the 1000 year inventory in the fuel. Should results from the Zirculoy corrosion testing show that the increase in defect numbers or size is too great to limit release rates to acceptable levels, a tailored packing material may be used to further reduce release rates.

\section{CONCLUSIONS}

Experiments conducted using Topopah Spring tuff and J-13 well water have been conducted to provide an esimate of the post-emplacement environment for waste packages in a repository at Yucca Mountain. The results show that emplacement of waste packages should cause only small changes in the water chemistry and rock mineralogy. The changes in environment should not have any detrimental effects on the performance of metal barriers or waste torins.

The NNWSI waste form testing program has provided preliminary results related to the release rate of radionuclides from the waste package. Those results indicate that release rates from both spent fuel and borosilicate glass should be below ; part in $10^{5}$ per year. Future testing will be directed toward making release rate testing more closely relevant to site spec fic conditions.

\section{REF ERENCES}

Bish, D. L., F. A. Caporuscio, J. F. Copp, B. M. Crowe, J. D. Purson, J. R. Smyth, and R. G. Warren, "Preliminary Stratigraphic and Petrologic Cnaracterization of Core Samples from USW-Gi, Yucca Mountain, Nevada", Los Alamos National Laboratory Report LA-8840-MS, 1981.

Caporuscio, F., D. Vaniman, D. Bish, D. Broxton, B. Arney, G. Heiken, F. Byers, R. Gooley, and R. Semarge, "Petrologic Studies of Core from Drill Hole USW-G2 and of the Lower Crater Flat Tuff in Core from Drill Hole UE25b-1H, Yucca Mountain, Nevada", Los Alamos National Laboratory Report LA-9255-M5, 1982. 
Dudley, W. W., Jr. and B. R. Erdal, "Site Characterization for Evaluation if Potential Nuclear Waste Isolation at Yucca Mountain, Nevada", Proceedings of the 1982 National Waste Terminal Storage Program Information Meeting, DOE/NWTS-30, 1982, pp. 10-12.

Knauss, K. G., V. M. Oversby and T. J. Wolery, "Post Emplacement Environment of Waste Packages", Lawrence Livermore National Laboratory Report UCRL-89425, 1983.

Knauss, K. G. and W. Beiriger, "Hydrothermal Interaction Studies of Topopah Spring Tuff Coro Wafers in J-13 Water", Lawrence Livermore National Laboratory Report, in preparation, 1984.

Knauss, K. G. and 0. Peifer, "Rocking Autoclave Studies Using Crushed Topopah Spring Tuff and J-13 Water", Lawrence Livermore National Laboratory Report, in preparation, 1984.

McCright, R. D., H. Weiss, M. C. Juhas and R. W. Logan, "Selection of Candidate Canister Materials for High-Level Nuclear Waste Containment in a Tuff Repository", Lawrence Livermore National Laboratory Report UCRL-89988, 1983.

McVay, G. L. "1 Review of Recent PNL Research Activities Related to Glass Leaching Mechanisms", Battelle Pacific Northwest Laboratory Report PNL-4382, 1982, pp. 74-83.

McVay, G. L. and G. R. Robinson, "Effects of Tuff Waste Package Components on Release from 76-68 Simulated Waste Glass", Battelle Pacific Northwest Laboratory Report (Draft) PNL-4897, 1983.

Morrow, C. A., D. E. Moore and J. D. Byerlee, "Permeability and Pore-Fluid Chemistry of the Topopah Spring Tuff, Nevada Test Site, in a Temperature Gradient", Proceedings of the 1983 Materials Research Society Symposium on the Scientific Basis for Nuclear Waste Management (in press) 1983.

Oversby, V. M. and K. G. Knauss, "Reaciion of Bullfrog Tuff with J-13 Well Water at $90^{\circ} \mathrm{C}$ and $150^{\circ} \mathrm{C} "$, Lawrence Livermore National Laborytory Report UCRL $-53442,1983$. 
Oversoy, V. M., "Reaction of the Topopah Spring Tuff witn J-13 Well Water at $90^{\circ} \mathrm{C}$ and $150^{\circ} \mathrm{C}$, , Lawrence Livermore National Laboratory Report, in preparation, 1984 a.

Oversby, V. M., "Reference Waste Forms and Packing Materials for the NNWSI Project", Lawrence Livermore National Laboratory Report, in preparation, 1984b.

Plodinec, M. J., G. G. Wicks and N. E. Bibler, "An Assessment of Savannan River Borosilicate Glass in the Repository Environment", Savannah River Laboratory Report DP-1629, 1982.

Sass, J. H. and A. H. Lachenbruch, "Prel ininary Interpretation of Therlic : . from the Nevada Test Site", U.S. Geological Survey Open File Report-82, 1982.

Vieth, 0. L., "Nevada Nuclear Waste Storage Investigations Project Overview", Proceedings of the 1982 National Waste Terminal Storage Program Information Meeting, DOE/NWTS-30, 1982, pp. 9-10.

Woodley, R. E., "The Characteristics of Spent LWR Fuel Relevant to its Storage in Geologic Repositories", Hanford Engineering Development Laboratory Report HEDL-TME 83-28, 1983. 